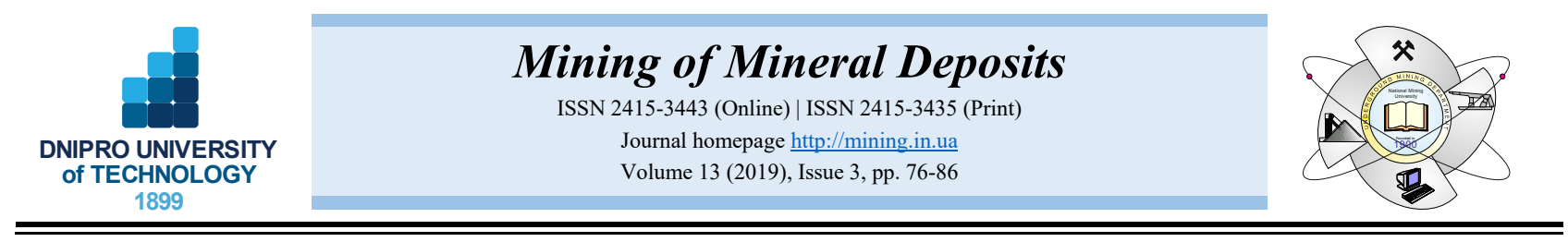

UDC 622.271.3:658.51

https://doi.org/10.33271/mining13.03.076

\title{
RISK ASSESSMENT OF BLASTING OPERATIONS IN OPEN PIT MINES USING FAHP METHOD
}

\author{
M. Kiani ${ }^{1}$, S.H. Hosseini ${ }^{1 *}$, M. Taji ${ }^{2}$, M. Gholinejad ${ }^{1}$ \\ ${ }^{1}$ Department of Mining Engineering, South Tehran Branch, Islamic Azad University, Tehran, Iran \\ ${ }^{2}$ Department of Petroleum and Mining Engineering, Shahroud Branch, Islamic Azad University, Shahroud, Iran \\ *Corresponding author: e-mail hoseini@azad.ac.ir, tel.+982133100609
}

\begin{abstract}
Purpose. In the mining blasting operation, fragmentation is the most important output. Fly rock, ground vibration, air blast, and environmental effects are detrimental effects of blasting operations. Identifying and ranking the risk of blasting operations is considered as the most important stage in project management.

Methods. In this research, the problem of identifying and ranking the factors constituting the risk in blasting operations is considered with the methodology of the Fuzzy Analytical Hierarchy Process (FAHP). Criteria and sub-criteria have been determined based on historical research studies, field studies, and expert opinions for designing a hierarchical process.

Findings. Based on FAHP scores, non-control of the sub-criterion of health and safety (C3), blast operation results (C18) and knowledge, and skill and staffing (C2) with a score of $0.377,0.334$, and 0.294 respectively are the most effective sub-criterion for the creation of blasting operations risk. According to the score, the sub-criterion $\mathrm{C} 18$ is the most effective sub-criterion in providing the blasting operations risk. Effects and results of blasting operations (D8), with a score of 0.334 as the most effective criterion, and natural hazards (D10), with a score of 0.015 , were the last priorities in the factors causing blasting operations risk.

Originality. Regarding the risk rating of blasting operations, the control of the sub-criteria $\mathrm{C} 3, \mathrm{C} 18$, and $\mathrm{C} 2$, and the D8 criterion, is of particular importance in reducing the risk of blasting operations and improving project management.

Practical implications. The evaluation of human resource performance and increase in the level of knowledge and skills and occupational safety and control of all outputs of blasting operations is necessary. Therefore, selecting the most important project risks and taking actions to remove them is essential for risk management.
\end{abstract}

Keywords: blasting operation, open pit mine, risk assessment, FAHP method, criteria and sub-criteria

\section{INTRODUCTION}

Engineering projects are typically designed and implemented under unavoidable circumstances of risks and uncertainties. Therefore, identification, measurement, and evaluation of hazards should be considered as integral and comprehensive components of the decision-making process (Haimes, 2009). In the meantime, mining is a high-risk industry due to its specific characteristics. With the extraction of more and more mines, the use of drilling and blasting operations is also expanding: more than $82 \%$ extraction and mining operations are carried out by the blasting process. Consequently, the importance of identifying and controlling the unwanted and destructive consequences of blasting operations have also increased (Taji \& Bagheri, 2015).

Identifying risk factors, knowing the extent and type of impacts and their proper ranking are key steps in correctly assessing and timely responding to risk and to minimizing damage to mining, machinery, facilities and manpower as a result of these events (Sayadi, Monjezi, \& Sharifi, 2014). In order to evaluate the risk of blasting operations in surface mines to reduce the adverse effects of blasting operations, it is necessary to examine the factors affecting blasting operations and to prioritize and grade these factors to identify the most important factors causing the risk of blasting operations.

Typically, blasting operations in mining projects are used for rock fragmentation (Bajpayee, Bhatt, Rehak, Mowrey, \& Ingram, 2003). Therefore, fragmentation control in blast operations is dependent on the explosion design and its impact on productivity. This is a challenge for explosive engineers due to inadequate knowledge of the amount of explosion energy in the blast hole and the variety of explosion initiation methods and their impact on the properties of explosion propagation (Singh et al., 2016). In surface mines, only 20 to $30 \%$ of the energy

(C) 2019. M. Kiani, S.H. Hosseini, M. Taji, M. Gholinejad. Published by the Dnipro University of Technology on behalf of Mining of Mineral Deposits This is an Open Access article distributed under the terms of the Creative Commons Attribution License (http://creativecommons.org/licenses/by/4.0/), which permits unrestricted reuse, distribution, and reproduction in any medium, provided the original work is properly cited. 
produced is used for compression and movement of the rock mass: the remaining energy often produces unwanted environmental effects and explosive effects, such as excessive air pressure, ground vibration, fly rock, dust production, and back break (Marto, Hajihassani, Jahed
Armaghani, Tonnizam Mohamad, \& Makhtar, 2014; Dhekne, 2015). So, in studies to assess the dangers of blasting operations, numerous parameters have been investigated by researchers in accordance with Table 1 in recent years.

Table 1. Blasting operation studies (2001 - 2017)

\begin{tabular}{|c|c|c|}
\hline No. & Author(s), year & Parameters \\
\hline 1 & Workman, 2001 & CR.P, DF, EL.CS, EN.CS, LP and OC \\
\hline 2 & Eloranta, 2001a; Eloranta, 2001b & CR.P, DF, DL, EC, EL.CS, LP, MT, SC and TC \\
\hline 4 & Grundstrom, Kanchibotla, Jankovic, \& Thornton, 2001 & DF, EL.CS, MT and SC \\
\hline 5 & Harris, Mousset, \& Daemen, 2001 & DF, DI, EC, MU and OC \\
\hline 6 & Singh \& Yalcin, 2002 & $\mathrm{DF}, \mathrm{DL}, \mathrm{EC}, \mathrm{MU}$ and $\mathrm{OC}$ \\
\hline 7 & Singh, Yalcin, Glogger, \& Narendrula, 2003 & $\mathrm{DF}, \mathrm{DL}, \mathrm{EC}, \mathrm{LP}$ and $\mathrm{OC}$ \\
\hline 8 & Bajpayee, Rehak, Mowrey, \& Ingram, 2004 & B.S, FR, HD, PF and SL \\
\hline 9 & Bajpayee, Verakis, \& Lobb, 2005 & B.S, HD, PF, SL and SR \\
\hline 10 & Cunningham, 2005 & CR.P, DF and LP \\
\hline 11 & Hamdi \& du Mouza, 2005 & CR.P, DF, MT and SD \\
\hline 12 & Kojovic, 2005 & $\mathrm{DF}, \mathrm{OC}$ and $\mathrm{SC}$ \\
\hline 13 & Mosher, 2005 & CR.P, DF, EC and OC \\
\hline 14 & Morin \& Ficarazzo, 2006 & $\mathrm{DF}, \mathrm{EC}, \mathrm{OC}$ and $\mathrm{SC}$ \\
\hline 15 & Ryu, Shim, Han, \& Ahn, 2006 & CR.P, DF, EC, OC and SB \\
\hline 16 & Bremer, Ethier, \& Lilly, 2007 & $\mathrm{DF}, \mathrm{EC}, \mathrm{SC}$ and SD \\
\hline 17 & Eloranta, 2007 & CR.P, DF, DL, EC, EL.CS, LP, MT, SC and TC \\
\hline 18 & Calder \& Workman, 2008 & DF, EC, EL.CS, LP, OC and SC \\
\hline 19 & Taji, 2008 & BP, BS, DF, MU and WC.H \\
\hline 20 & Workman \& Eloranta, 2008 & DF, EL.CS, EN.CS, OC and SB \\
\hline 21 & Calder \& Workman, 2009 & DF, EC, EL.CS, LP, OC and SC \\
\hline 22 & Monjezi, Bahrami, Varjani, \& Sayadi, 2011 & B.S, FL, HD, PF, SC and SL \\
\hline 23 & Rezaei, Monjezi, \& Yazdian Varjani, 2011 & B.S, FL, HD, PF, SC, SD and SL \\
\hline 24 & Verakis, 2011 & E.CO, FR \\
\hline 25 & Taji, Ataei, Goshtasbi, \& Osanloo, 2012 & BB, BP, DF, E.CO, LP and MU \\
\hline 26 & Faramarzi, Ebrahimi Farsangi, \& Mansouri, 2013 & B.S, DF, HD and PF \\
\hline 27 & Faramarzi, Mansouri, \& Ebrahimi Farsangi, 2013 & BB, B.S, HD, Im and PF \\
\hline 28 & $\begin{array}{l}\text { Armaghani, Hajihassani, Mohamad, } \\
\text { Marto, \& Noorani, } 2013\end{array}$ & B.S, FR, GV, HD, PF and SL \\
\hline 29 & Sayadi, Monjezi, Talebi, \& Khandelwal, 2013 & BB, B.S, DF, HD, SC, SD and SL \\
\hline 30 & Seccatore, Origliasso, \& De Tomi, 2013 & B.S, PF and SL \\
\hline 31 & Faramarzi, Mansouri, \& Farsangi, 2014 & B.S, FL, HD, SC and SL \\
\hline 32 & $\begin{array}{l}\text { Marto, Hajihassani, Jahed Armaghani, } \\
\text { Tonnizam Mohamad, \& Makhtar, } 2014\end{array}$ & B.S, HD, PF and SL \\
\hline 33 & Saadat, Khandelwal, \& Monjezi, 2014 & GV \\
\hline 34 & Trivedi, Singh, \& Raina, 2014 & B.S, FR, HD, SC and SL \\
\hline 35 & Dhekne, 2015 & B.S, E.Co, HD and SL \\
\hline 36 & Raina, Murthy, \& Soni, 2015 & FL, B.S, SL, SC and HD \\
\hline 37 & Asri \& Daafi, 2016 & $\mathrm{BB}, \mathrm{BH}, \mathrm{B} . \mathrm{S}, \mathrm{Im}, \mathrm{PF}$ and SL \\
\hline 38 & Hasanipanah, Jahed Armaghani, Monjezi, \& Shams, 2016 & DF, B.S and blasting design and rock mass parameters \\
\hline 39 & Hoseini, Sereshki, \& Ataei 2016 & B.S, HD, SD and SL \\
\hline 40 & Kumar, Choudhury, \& Bhargava, 2016 & $\mathrm{GV}$ \\
\hline 41 & Singh et al., 2016 & B.S, DF, PF and SL \\
\hline 42 & Tripathy, Shirke, \& Kudale, 2016 & B.S, HD, PF, SC, SD and SL \\
\hline 43 & Bakhtavar, Nourizadeh, \& Sahebi, 2017 & B.S, FR, HD and SL \\
\hline 44 & Ghaeini, Mousakhani, Amnieh, \& Jafari, 2017 & B.S, SC and SL \\
\hline 45 & Ghasemi, 2017 & $\mathrm{BB}$ \\
\hline 46 & Yari, Bagherpour, \& Jamali, 2015 & B.S, HD and SL \\
\hline 47 & Yuvka, Beyhan, \& Uysal, 2017 & $\mathrm{GV}$, number of holes \\
\hline
\end{tabular}

BB - back break; BH - bench height; BP - boulder production; BS - block size; B.S - burden to spacing; Cr.P - crusher productivity and delays at the crusher; DF - degree of fragmentation and required size distribution of fragmented rocks; DI - dilution constrains; DL - diggability of loading machines; EC - explosive cost; E.Co - environmental considerations; El.Cs - electrical consumption; En.Cs - energy consumption; FR - fly rock; GV - ground vibration; HD - hole depth; Im - initiation method; LP - loading equipment productivity; MT - mill throughput; $\mathrm{Mu}$ - condition of muckpile; OC - operational (blasting, drilling or loading) cost; PE - personnel expert; PF - powder factor; SB - secondary blasting; SC - specific charge; SD - specific drilling; SL - stemming length; SR - safety regulation; TC - total costs of mining; WC.H - water content in hole. 
In order to more accurately identify the hazards and to investigate the impact of any risk in the field of blasting operations in mines, it is necessary to classify and rank the risk of the blasting operations in order to identify the most significant factors that cause risk during blasting operations. As a result, the main criteria for the risk of blasting operations in the ten main groups of human resources, execution factors, operational conditions, rock engineering, drilling operations, blasting operation design, explosive block, effects and results of blasting operations, production and extraction consideration, and natural hazards are based on study of the open pit mines Gol-e-Gohar Iron Ore, Bama Lead and Zinc Mine, Sarcheshmeh Copper Mine, and Isfahan Stone Mobarake Iron \& Steel Co.; historical research in this context was also identified. Each major criterion was subdivided according to the criteria that influence the main criterion. The main criteria of human resources, execution factors, operational conditions, and blasting operation design were divided into a number of sub-criteria: these were important in the process of studying and rating by experts. In this category of criteria, the comparison and consideration of the importance of sub-criteria is necessary.

\section{BLASTING OPERATIONS RISKS}

Identification of the risk of blasting operations is based on the process of identifying, recognizing, and recording the risks of blasting operations. The purpose of identifying the risk of a blasting operation is to determine what might happen and what situations may exist that could affect the achievement of the project's objectives. When identifying the risk of a blasting operation, all existing controls, such as design parameters, humans, processes, and systems must be identified. The risk identification process involves identifying the causes and sources of risk, events, situations, or conditions that could have a general impact on the purposes and nature of the blasting operation.

Methods for identifying the risk of blasting operations can include:

- evidence-based methods, including checklists and revision of historical data;

- systematic group approaches in which a group of professionals follow a systematic process to identify risks through a structured set of notifications or queries.

According to the methods for identification of the risk of blasting operations and the review of open pit mines as a case study, and considering background research studies, the considered criteria as well as the risks of explosion operations are classified as options in Figure 1.

\section{FUZZY ANALYTICAL HIERARCHY PROCESS (FAHP)}

In order to analyze critical infrastructure, comprehensive knowledge and information is needed. On the other hand, despite the connection between complexity and trust, so that increasing complexity leads to a reduction of assurance, it is necessary to provide an appropriate model for a more detailed study of project conditions (Ebrahimabadi, 2016). The Fuzzy Logic introduced by Professor A. Lotfizadeh, is an appropriate tool for verifying unspecified information and fuzzy phrases (Zadeh, 1965).

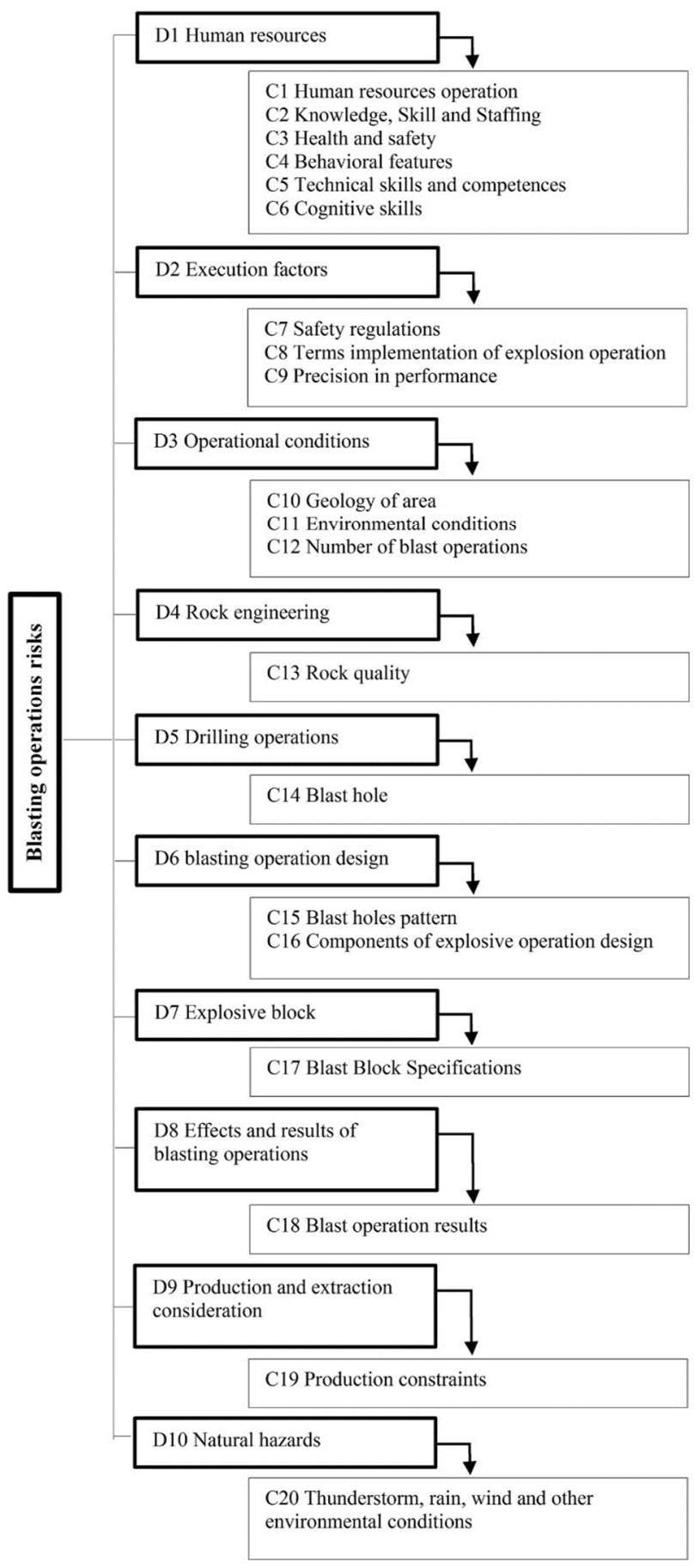

Figure 1. Hierarchical structure of blast operation risks

According to the development of fuzzy methods, the Analytical Hierarchy Process (AHP) developed by T.L. Saaty in 1980 for Multi-Criteria Decision-Making (MCDM) was presented to determine the priority among alternatives and to improve the decision-making method in terms of its qualitative and quantitative aspects (Saaty, 1980).

This method was defined in (Lee, Lau, Liu, \& Tam, 2001), as a quantitative technique so that the structure of a complex, multi-faceted problem can be facilitated and dealt with differently from various decisions in the judgment process. In this way, decomposition is a hierarchy based on previous studies, research, and experimental experiences. With the development of hierarchy, an assessment of the relative importance of decision-making 
criteria is made. Then, the decision options are determined according to available comparison criteria, if any. Ultimately, the overall priority for each decision substitute and the overall ranking of alternative decisions is determined.

Assessing the relative importance of decision-making criteria and comparing decision alternatives to each criterion is done with a dual comparison (Lee, Lau, Liu, \& Tam, 2001). Therefore, the AHP enables the DecisionMaker (DM) to examine a complex problem in a simple hierarchy and evaluate a large number of quantitative and qualitative factors in a regular system with multiple criteria (Badri, 1999; Kaboli, Aryanezhad, Shahanaghi, \& Tavakkoli-Moghaddam, 2007). Since this selection process generally involves evaluating various criteria and characteristics of the supplier, it can be considered as a MCDM system (Ayhan, 2013).

In AHP, the computation process is divided into two stages: screening and evaluation (Rikalovic, Cosic, Labati, \& Piuri, 2017). At first, the decision problem decomposes into a hierarchical structure with decision elements. This method involves six steps: structured problem definition, hierarchy creation, dual comparison, relative weight estimation, validation, and ultimately overall score (Safari, Ataei, Khalokakaie, \& Karamozian, 2010). Subsequently, the fuzzy method provides the development of a standard method AHP in a fuzzy domain using fuzzy numbers to compute them instead of real numbers (Petkovic, Sevara, Jaksic, \& Marinkovic, 2012). Using the theory of fuzzy sets allows decision-makers to consider uncertain information, incomplete information, inaccessible information, and minor facts in the decision model (Chou, Hsu, \& Chen, 2008).

\subsection{Determining criteria}

Determining the criteria for evaluation using hierarchical charts, defining fuzzy numbers and forming a pairwise comparison matrix can be investigated.

\subsubsection{Drawing a hierarchical chart}

The first step in the fuzzy AHP method is to decompose the decision problem into various levels of the target, criteria, sub-criteria, and options. The hierarchical decision graph shows the comparative factors and competitive options evaluated in the decision. For this purpose, it is necessary to create a graphical representation of the problem.

\subsubsection{Defining fuzzy numbers}

A triangular fuzzy number (TFN) must have the following basic characteristics. The fuzzy number $\tilde{A}$ in $R$ is considered as TFN if its membership function is equal to (Hsieh, Lu, \& Tzeng, 2004):

$$
\begin{aligned}
& \mu_{\tilde{A}}(X): R[0,1] ; \\
& \mu_{\tilde{A}}=\left[\begin{array}{l}
\left(\frac{X-L}{M-L}\right), L \ll X \ll M \\
\left(\frac{U-X}{U-M}\right), M \ll X \ll U \\
0,
\end{array}\right],
\end{aligned}
$$

where:
$L$ and $U$-are considered as the lower and upper bounds of the fuzzy number $\tilde{A}$ and $M$ as modal values according to Figure 2.

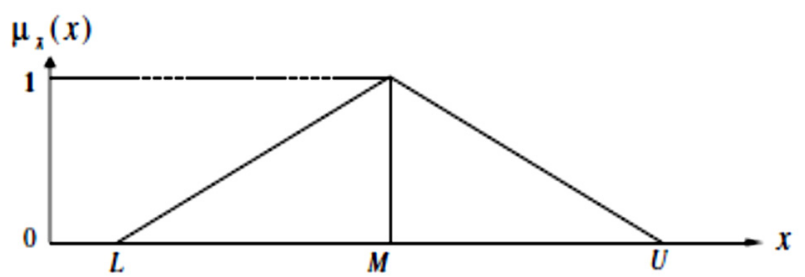

Figure 2. Fuzzy numbers membership function (Hsieh, Lu, \& Tzeng, 2004)

According to (Zadeh, 1975a; Zadeh, 1975b), for a conventional measurement, it is very difficult to logically define conditions that are clearly complex or difficult; the concept of a linguistic variable is necessary in such circumstances. Here, using this form of expression, five basic linguistic terms emerge to facilitate comparison of the criteria: absolutely important, very strongly important, essentially important, weakly important, and equally importance. These terms are used according to the fuzzy membership function, shown for the language variables in Figure 3 (Hsieh, Lu, \& Tzeng, 2004).

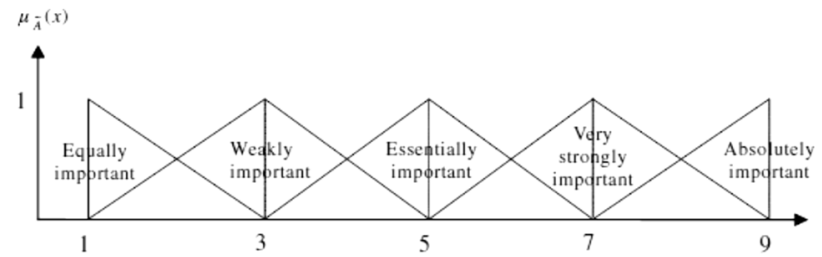

Figure 3. Fuzzy membership function for language variables (Hsieh, Lu, \& Tzeng, 2004)

In a fuzzy hierarchical analysis method, decision-makers are asked to compare the elements of each row after providing a hierarchical graph. This is illustrated in Table 2, which represents an example of fuzzy numbers and the relative importance of the elements expressed by using fuzzy numbers.

Table 2. Membership function of fuzzy numbers

\begin{tabular}{ccc}
\hline $\begin{array}{c}\text { Fuzzy } \\
\text { number }\end{array}$ & $\begin{array}{c}\text { Linguistic } \\
\text { scales }\end{array}$ & $\begin{array}{c}\text { Scale of fuzzy } \\
\text { number }\end{array}$ \\
\hline$\tilde{1}$ & Equal importance & $(1,1,3)$ \\
$\tilde{3}$ & Weakly important & $(1,3,5)$ \\
$\tilde{5}$ & Essentially important & $(3,5,7)$ \\
$\tilde{7}$ & Very strongly important & $(5,7,9)$ \\
$\tilde{9}$ & Absolutely important & $(7,9,9)$ \\
\hline
\end{tabular}

\subsubsection{Formation of a comparative} matrix $\tilde{A}$ by applying fuzzy numbers

Pairwise comparison matrix is:

$\tilde{A}=\left[\begin{array}{cccc}1 & \tilde{a}_{12} & \ldots & \tilde{a}_{1 n} \\ \tilde{a}_{21} & 1 & \ldots & \tilde{a}_{2 n} \\ \tilde{a}_{n 1} & \tilde{a}_{n 2} & \ldots & 1\end{array}\right]$.

This matrix contains the following fuzzy numbers: 


$$
\tilde{a}_{i j}=\left\{\begin{array}{ll}
1 & i=j \\
\tilde{1}, \tilde{3}, \tilde{5}, \tilde{7}, \tilde{9} & i \neq j
\end{array} .\right.
$$

For geometric averaging of expert opinions and weighting criteria, Buckley's method (Buckley, 1985) can be used as follows:

$$
\begin{aligned}
& \tilde{r}_{i}=\left(\tilde{a}_{i 1} \otimes \tilde{a}_{i 2} \otimes \ldots \otimes \tilde{a}_{i n}\right)^{\frac{1}{n}} ; \\
& \tilde{w}_{i}=\tilde{r}_{i} \otimes\left(\tilde{r}_{1} \otimes \ldots \otimes \tilde{r}_{n}\right)^{-1},
\end{aligned}
$$

where:

$\tilde{a}_{i n}-$ value of fuzzy comparison of criterion $i$ to $n$;

$\tilde{r}_{i}$-value of geometric mean of fuzzy comparison value of criterion $i$;

$\tilde{w}_{i}-$ the fuzzy weight of the ith criterion, which can be indicated by a TFN;

$\tilde{w}_{i}=\left(L_{w i}, M_{w i}, U_{w i}\right)$ stand for values of the lower, middle, and upper of the fuzzy weight of the ith criterion.

Finally, in order to rank the criteria, it is necessary to convert fuzzy numbers to non-fuzzy numbers. In this study, Best Non-fuzzy Performance Value (BNP). Method was used for defuzzy numbers. BNP value of the fuzzy number $R$ can be found by the equation (6) (Hsieh, Lu, \& Tzeng, 2004):

$$
B N P_{i}=\frac{\left[\left(U R_{i}-L R_{i}\right)+\left(M R_{i}-L R_{i}\right)\right]}{3}+L R_{i} .
$$

Ultimately, by multiplying the weights of the corresponding criteria, the final weight of each under the criteria is obtained.

\section{RATINGS OF BLASTING OPERATIONS RISKS}

In this study, after drawing a hierarchy in accordance with the conditions of the blasting operation and according to the experts' opinion, the scores were evaluated using the FAHP method to compare the pair between the criteria and each of the sub-criteria. Therefore, according to the

\begin{tabular}{|c|c|c|c|c|c|c|c|c|c|c|}
\hline & $\mathrm{D} 1$ & $\mathrm{D} 2$ & D3 & D4 & D5 & D6 & D7 & D8 & D9 & $\mathrm{D} 10$ \\
\hline $\mathrm{D} 1$ & 1 & $\tilde{3}$ & $\tilde{3}$ & $\tilde{q}$ & $\tilde{7}$ & $\tilde{1}$ & 5 & $\tilde{7}^{-1}$ & $\tilde{5}$ & 7 \\
\hline $\mathrm{D} 2$ & $\tilde{3}^{-1}$ & 1 & $\tilde{1}$ & $\tilde{5}$ & $\tilde{7}$ & $\tilde{3}^{-1}$ & $\tilde{3}$ & $\tilde{5}^{-1}$ & $\tilde{7}$ & $\tilde{9}$ \\
\hline D3 & $\tilde{3}^{-1}$ & $\tilde{1}$ & 1 & $\tilde{7}$ & $\tilde{5}$ & $\tilde{3}^{-1}$ & $\tilde{3}$ & $\tilde{7}^{-1}$ & $\tilde{5}$ & $\tilde{7}$ \\
\hline D4 & $\tilde{9}^{-1}$ & $\tilde{5}^{-1}$ & $\tilde{7}^{-1}$ & 1 & $\tilde{5}^{-1}$ & $\tilde{7}^{-1}$ & $\tilde{5}^{-1}$ & $\tilde{9}^{-1}$ & $\tilde{5}^{-1}$ & $\tilde{1}$ \\
\hline D5 & $\tilde{7}^{-1}$ & $\tilde{7}^{-1}$ & $\tilde{5}^{-1}$ & $\tilde{5}$ & 1 & $\tilde{5}^{-1}$ & $\tilde{1}$ & $\tilde{7}^{-1}$ & $\tilde{1}$ & \\
\hline D6 & $\tilde{1}$ & $\tilde{3}$ & $\tilde{3}$ & 7 & $\tilde{5}$ & 1 & $\tilde{3}$ & $\tilde{5}^{-1}$ & $\tilde{5}$ & 7 \\
\hline D7 & $\tilde{5}^{-1}$ & $\tilde{3}^{-1}$ & $\tilde{3}^{-1}$ & $\tilde{5}$ & $\tilde{1}$ & $\tilde{3}^{-1}$ & 1 & $\tilde{5}^{-1}$ & $\tilde{5}$ & \\
\hline D8 & $\tilde{7}$ & $\tilde{5}$ & $\tilde{7}$ & 7 & $\tilde{7}$ & $\tilde{5}$ & $\tilde{5}$ & 1 & $\tilde{7}$ & \\
\hline D9 & $\tilde{5}^{-1}$ & $\tilde{7}^{-1}$ & $\tilde{5}^{-1}$ & $\tilde{5}$ & $\tilde{1}$ & $\tilde{5}^{-1}$ & $\tilde{5}^{-1}$ & $\tilde{7}^{-1}$ & 1 & $J$ \\
\hline D10 & $\tilde{7}^{-1}$ & $\tilde{g}^{-1}$ & $\tilde{7}^{-1}$ & $\tilde{1}$ & $\tilde{5}^{-1}$ & $\tilde{7}^{-1}$ & $\tilde{7}^{-1}$ & $\tilde{q}^{-1}$ & $\tilde{5}^{-1}$ & 1 \\
\hline
\end{tabular}
experts' opinion, paired comparison matrices of the criteria were adjusted according to matrices $\mathrm{A}, \mathrm{B}$, and $\mathrm{C}$ (Figs. $4-6$ ).

Figure 4. Matrix A, paired comparison of main criteria: Expert $A$

\begin{tabular}{|c|c|c|c|c|c|c|c|c|c|c|}
\hline & D1 & D2 & D3 & D4 & D5 & D6 & D7 & D8 & $\mathrm{D} 9$ & \\
\hline 1 & 1 & $\tilde{3}$ & $\tilde{5}$ & $\tilde{a}$ & $\tilde{5}$ & $\tilde{3}^{-1}$ & $\tilde{3}$ & $q^{-1}$ & 7 & \\
\hline & $\tilde{3}^{-1}$ & 1 & $\tilde{3}$ & $\tilde{9}$ & & $\tilde{1}$ & $\tilde{3}$ & $\tilde{7}^{-1}$ & $\tilde{5}$ & \\
\hline & $\tilde{5}^{-1}$ & $\tilde{3}^{-1}$ & 1 & $\tilde{5}$ & & 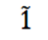 & $\tilde{5}$ & $\tilde{5}^{-1}$ & $\tilde{3}$ & \\
\hline & $\tilde{9}^{-1}$ & $\tilde{q}^{-1}$ & $\tilde{5}^{-1}$ & 1 & $\tilde{1}$ & $\tilde{5}^{-1}$ & $\tilde{3}^{-1}$ & $\tilde{g}^{-1}$ & $\tilde{3}^{-}$ & \\
\hline 25 & $\tilde{5}^{-1}$ & $\tilde{3}^{-1}$ & $\tilde{3}^{-1}$ & $\tilde{1}$ & 1 & $\tilde{3}^{-1}$ & $\tilde{3}^{-1}$ & $\tilde{1}$ & $\tilde{7}^{-}$ & \\
\hline & $\tilde{3}$ & $\tilde{1}$ & $\tilde{1}$ & $\tilde{5}$ & $\tilde{3}$ & 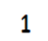 & $\tilde{3}$ & $\tilde{5}^{-1}$ & $\tilde{3}$ & \\
\hline 27 & $\tilde{3}^{-1}$ & $\tilde{3}^{-1}$ & $\tilde{5}^{-1}$ & 3 & $\tilde{3}$ & $\tilde{3}^{-1}$ & 1 & $\tilde{5}^{-1}$ & 3 & \\
\hline 08 & 7 & 7 & $\tilde{\tilde{z}}$ & $\tilde{\tilde{n}}$ & 7 & $\tilde{\tilde{n}}$ & 5 & 1 & 7 & \\
\hline & $\tilde{7}^{-1}$ & $\tilde{5}^{-1}$ & 3 & $\tilde{3}$ & $\tilde{1}$ & $\tilde{3}^{-1}$ & $\tilde{3}^{-1}$ & $\tilde{7}^{-1}$ & 1 & \\
\hline & $\tilde{\tilde{n}}$ & $\tilde{7}^{-1}$ & $\tilde{5}^{-1}$ & $\tilde{3}^{-1}$ & $\tilde{3}^{-1}$ & $\tilde{5}^{-1}$ & $\tilde{7}^{-1}$ & $\tilde{q}^{-1}$ & $\tilde{3}^{-1}$ & \\
\hline
\end{tabular}

Finally, in order to integrate the experts' opinion and achieve a single matrix (matrix D) (Fig. 7), a geometric

\begin{tabular}{|c|c|c|c|c|c|c|c|c|c|c|}
\hline & D1 & D2 & D3 & D4 & D5 & D6 & D7 & D8 & $D 9$ & \\
\hline D1 & 1 & $\tilde{1}$ & $\tilde{5}$ & $\tilde{7}$ & $\tilde{5}$ & $\tilde{3}^{-1}$ & $\tilde{5}$ & $\tilde{5}^{-1}$ & $\tilde{7}$ & \\
\hline & $\tilde{1}$ & 1 & $\tilde{3}$ & $J$ & $\tilde{3}$ & $\tilde{1}$ & $\tilde{5}$ & $\tilde{q}^{-1}$ & $\tilde{3}$ & \\
\hline & $\tilde{5}^{-1}$ & $\tilde{3}^{-1}$ & 1 & $\tilde{5}$ & $\tilde{5}$ & $\tilde{1}$ & $\tilde{5}$ & $\tilde{3}^{-1}$ & $\tilde{3}$ & \\
\hline 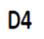 & $\tilde{7}^{-1}$ & $\tilde{5}^{-1}$ & $\tilde{5}^{-1}$ & 1 & $\tilde{1}$ & $\tilde{3}^{-1}$ & $\tilde{5}^{-1}$ & $\tilde{q}^{-1}$ & $\tilde{3}^{-1}$ & \\
\hline 25 & $\tilde{5}^{-1}$ & $\tilde{3}^{-1}$ & $\tilde{5}^{-1}$ & $\tilde{1}$ & 1 & $\tilde{3}^{-1}$ & $\tilde{3}^{-1}$ & $\tilde{7}^{-1}$ & $\tilde{3}^{-1}$ & \\
\hline 06 & $\tilde{3}$ & $\tilde{1}$ & $\tilde{1}$ & $\tilde{3}$ & $\tilde{3}$ & 1 & $\tilde{3}$ & $\tilde{3}^{-1}$ & $\tilde{5}$ & \\
\hline D7 & $\tilde{5}^{-1}$ & $\tilde{5}^{-1}$ & $\tilde{5}^{-1}$ & $\tilde{5}$ & $\tilde{3}$ & $\tilde{3}^{-1}$ & 1 & $7^{-1}$ & $\tilde{3}$ & \\
\hline D8 & $\tilde{5}$ & $\tilde{9}$ & $\tilde{3}$ & $\tilde{9}$ & $\tilde{7}$ & $\tilde{3}$ & $\tilde{7}$ & 1 & $\tilde{7}$ & \\
\hline c & $\tilde{7}^{-1}$ & $\tilde{3}^{-1}$ & $\tilde{3}^{-1}$ & $\tilde{3}$ & $\tilde{3}$ & $\tilde{5}^{-1}$ & $\tilde{3}^{-1}$ & $\tilde{7}^{-1}$ & 1 & \\
\hline & $\tilde{q}^{-1}$ & $\tilde{7}^{-1}$ & $\tilde{7}^{-1}$ & $\tilde{3}^{-1}$ & $\tilde{5}^{-1}$ & $\tilde{7}^{-1}$ & $\tilde{7}^{-1}$ & $\tilde{q}^{-1}$ & $\tilde{5}^{-1}$ & \\
\hline
\end{tabular}
mean method was used in accordance with equation (5).
Figure 5. Matrix B, paired comparison of main criteria: Expert B

Figure 6. Matrix C, paired comparison of main criteria: Expert C

In the following, the matrix of the sub-criteria was also adjusted and, finally, was calculated as a single matrix for each sub-criterion by the geometric mean method. The average matrix of the group of sub-criteria is equal to the matrices C-D1, C-D2, C-D3, and C-D6.

The average of pairings' comparison of these matrices is provided in Figures $8-11$. The specified criteria have a positive impact on blasting operations risks. This means that increase in the score of one criterion is based on experts' opinions over and above other criteria: this increases the level of the impact of the critical level of risk.

Considering the importance of the weights of the criteria in the pairwise matrices, the fuzzy weight obtained from the criteria and the sub criteria is given in Table 3.

\section{RESULTS AND DISCUSSION}

According to the scores of criteria and sub criteria, the weight of each criterion in its sub-criteria emerging from the FAHP method gives scores associated with each subcriterion as provided in Table 4. Criterion of effects and results of blasting operations (D8) with score 0.334 were determined as the most effective criterion in blasting operations risk. Therefore, to reduce blasting operation risk it is necessary to examine, first and foremost, the factors that create this criterion. The larger aim herein is to control the outputs of the blast operation, including worse fragmentation, boulder production, back break, side break, pivot (toe) creation, misfire, noise production, ground vibration, air blast, fly rock, production of toxic gases from the explosion, dust production, premature blast, and inappropriate stability of remaining bench face. The remaining work chest is of particular importance. It should be noted that controlling some of these cases is related to human resources control as well as the principles of blasting design. Therefore, consideration of other criteria is also necessary. 


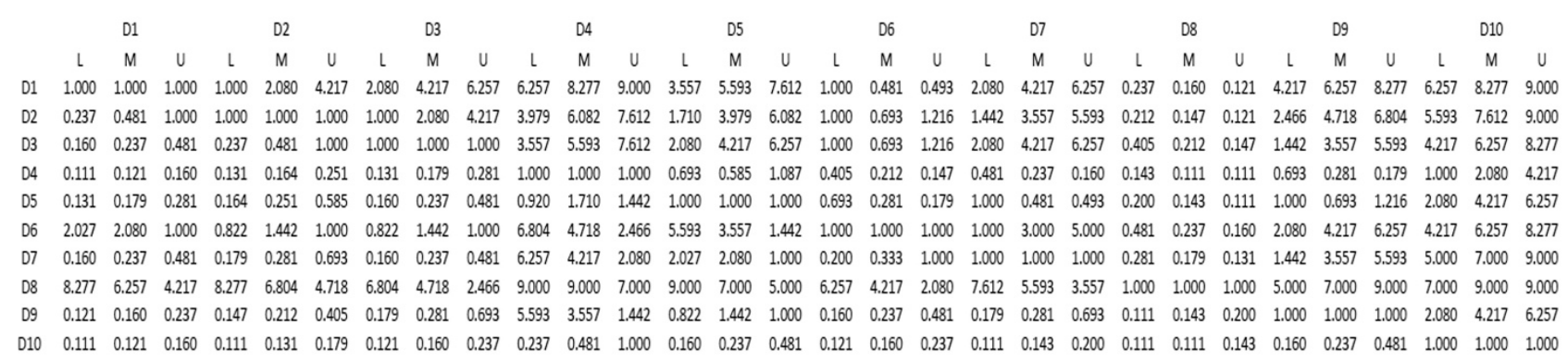

Figure 7. Matrix D, Average experts' opinion according to the main criteria

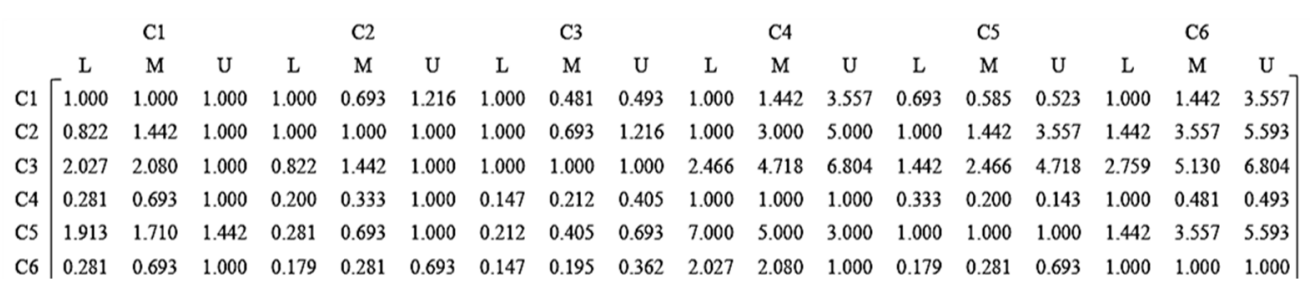

Figure 8. Matrix C-D1, the average of experts' opinion on sub-criteria group of the criteria D1

\begin{tabular}{|c|c|c|c|c|c|c|c|c|c|}
\hline & \multicolumn{3}{|c|}{ C7 } & \multicolumn{3}{|c|}{ C8 } & \multicolumn{3}{|c|}{ C9 } \\
\hline & L & M & U & L & M & U & L & M & $\mathrm{U}$ \\
\hline C7 & 1.000 & 1.000 & 1.000 & 1.442 & 1.710 & 3.979 & 1.442 & 3.557 & 5.593 \\
\hline C8 & 0.251 & 0.585 & 0.693 & 1.000 & 1.000 & 1.000 & 1.000 & 2.080 & 4.217 \\
\hline C9 & 0.179 & 0.281 & 0.693 & 0.237 & 0.481 & 1.000 & 1.000 & 1.000 & 1.000 \\
\hline
\end{tabular}

Figure 9. Matrix C-D2, the average of experts' opinion on subcriteria group of the criteria D2

\begin{tabular}{|c|c|c|c|c|c|c|c|c|c|}
\hline & \multicolumn{3}{|c|}{$\mathrm{C} 10$} & \multicolumn{3}{|c|}{ C11 } & \multicolumn{3}{|c|}{$\mathrm{C} 12$} \\
\hline & L & M & U & L & M & U & L & M & U \\
\hline C10 & 1.000 & 1.000 & 1.000 & 0.693 & 0.281 & 0.179 & 0.693 & 0.405 & 0.441 \\
\hline C11 & 5.593 & 3.557 & 1.442 & 1.000 & 1.000 & 1.000 & 1.000 & 3.000 & 5.000 \\
\hline $\mathrm{C} 12$ & 2.268 & 2.466 & 1.442 & 0.200 & 0.333 & 1.000 & 1.000 & 1.000 & 1.000 \\
\hline
\end{tabular}

Figure 10. Matrix C-D3, the average of experts' opinion on sub-criteria group of the criteria $D 3$

\begin{tabular}{|c|c|c|c|c|c|c|}
\hline & \multicolumn{3}{|c|}{$\mathrm{C} 15$} & \multicolumn{3}{|c|}{$\mathrm{C} 16$} \\
\hline & $\mathrm{L}$ & M & $\mathrm{U}$ & L & $\mathrm{M}$ & $\mathrm{U}$ \\
\hline $\mathrm{C} 15$ & {$[1.000$} & 1.000 & 1.000 & 0.693 & 0.281 & 0.179 \\
\hline $\mathrm{C} 16$ & 5.593 & 3.557 & 1.442 & 1.000 & 1.000 & 1.000 \\
\hline
\end{tabular}

Figure 11. Matrix C-D6, the average of experts' opinion on sub-criteria group of the criteria $D 6$

The second most effective criterion determining the risk of blasting operations is criterion D1. This criterion includes the sub-criteria regarding the performance and knowledge of manpower in the process of blast operations. Identifying and controlling this criterion is essential in order to prevent damage to human resources and reduce potential risks associated with the risk of blasting operations.

It has also been observed by examining the privileges of all the sub-criteria that occupational health and safety (C3) including job stress, safety risks of workshop and site, and imbalance of work and life with a score of 0.377 is the first sub-criterion and sub-criterion $(\mathrm{C} 18)$ with a score of 0.334 is the second sub-criterion of blasting operation risk factors. On the other hand, natural hazards (D10) and sub-criterion (C20) with the introduction of thunderstorms, rain, wind, and other environmental conditions with a score of 0.015 have the least priority amongst factors causing blast operation risk.
Table 3. Fuzzy weights obtained from criteria and sub-criteria

\begin{tabular}{cccc}
\hline $\begin{array}{c}\text { Criteria and } \\
\text { sub-criteria }\end{array}$ & \multicolumn{3}{c}{ Local weight } \\
\hline D1 & 0.117 & 0.157 & 0.211 \\
C1 & 0.748 & 1.000 & 1.337 \\
C2 & 0.818 & 1.833 & 2.364 \\
C3 & 1.266 & 2.760 & 2.608 \\
C4 & 0.298 & 0.476 & 0.588 \\
C5 & 0.814 & 1.662 & 1.701 \\
C6 & 0.296 & 0.616 & 0.794 \\
D2 & 0.075 & 0.115 & 0.179 \\
C7 & 0.249 & 0.536 & 1.247 \\
C8 & 0.123 & 0.313 & 0.634 \\
C9 & 0.068 & 0.151 & 0.392 \\
D3 & 0.064 & 0.093 & 0.145 \\
C10 & 0.224 & 0.134 & 0.129 \\
C11 & 0.509 & 0.608 & 0.581 \\
C12 & 0.220 & 0.259 & 0.340 \\
D4 & 0.021 & 0.020 & 0.025 \\
C13 & 1.000 & 1.000 & 1.000 \\
D5 & 0.031 & 0.033 & 0.044 \\
C14 & 1.000 & 1.000 & 1.000 \\
D6 & 0.106 & 0.133 & 0.118 \\
C15 & 0.513 & 0.219 & 0.132 \\
C16 & 1.457 & 0.781 & 0.376 \\
D7 & 0.042 & 0.055 & 0.077 \\
C17 & 1.000 & 1.000 & 1.000 \\
D8 & 0.371 & 0.346 & 0.286 \\
C18 & 1.000 & 1.000 & 1.000 \\
D9 & 0.024 & 0.035 & 0.052 \\
C19 & 1.000 & 1.000 & 1.000 \\
D10 & 0.010 & 0.014 & 0.023 \\
C20 & 1.000 & 1.000 & 1.000 \\
\hline & & &
\end{tabular}

Therefore, in assessing the risks of explosive operations, considering all the effective criteria is important: firstly, the criteria of the effects and results of blasting operation, and then the human resources. After reviewing and ranking the sub-criteria, the sub-criteria related to human resources appear to be of particular importance. Further, other criteria based on the score obtained have significant effects on the risk of blasting operations. 
Table 4. Final Scores of Criteria and Sub-criteria for blasting operation risks

\begin{tabular}{|c|c|c|c|c|c|c|c|c|}
\hline $\begin{array}{l}\text { Cri- } \\
\text { teria }\end{array}$ & & cal wei & & Ove & rall we & ight & BNP & Rank \\
\hline D1 & 0.117 & 0.157 & 0.211 & & & & 0.162 & 2 \\
\hline $\mathrm{C} 1$ & 0.748 & 1.000 & 1.337 & 0.087 & 0.157 & 0.282 & 0.176 & 4 \\
\hline $\mathrm{C} 2$ & 0.818 & 1.833 & 2.364 & 0.096 & 0.287 & 0.499 & 0.294 & 3 \\
\hline $\mathrm{C} 3$ & 1.266 & 2.760 & 2.608 & 0.148 & 0.432 & 0.551 & 0.377 & 1 \\
\hline $\mathrm{C} 4$ & 0.298 & 0.476 & 0.588 & 0.035 & 0.075 & 0.124 & 0.078 & 8 \\
\hline $\mathrm{C} 5$ & 0.814 & 1.662 & 1.701 & 0.095 & 0.260 & 0.359 & 0.238 & 5 \\
\hline C6 & 0.296 & 0.616 & 0.794 & 0.035 & 0.097 & 0.168 & 0.100 & 7 \\
\hline D2 & 0.075 & 0.115 & 0.179 & & & & 0.123 & 3 \\
\hline $\mathrm{C} 7$ & 0.249 & 0.536 & 1.247 & 0.019 & 0.062 & 0.224 & 0.101 & 6 \\
\hline C8 & 0.123 & 0.313 & 0.634 & 0.009 & 0.036 & 0.114 & 0.053 & 10 \\
\hline C9 & 0.068 & 0.151 & 0.392 & 0.005 & 0.017 & 0.070 & 0.031 & 13 \\
\hline D3 & 0.064 & 0.093 & 0.145 & & & & 0.101 & 5 \\
\hline $\mathrm{C} 10$ & 0.224 & 0.134 & 0.129 & 0.014 & 0.012 & 0.019 & 0.015 & 16 \\
\hline C11 & 0.509 & 0.608 & 0.581 & 0.033 & 0.057 & 0.084 & 0.058 & 9 \\
\hline $\mathrm{C} 12$ & 0.220 & 0.259 & 0.340 & 0.014 & 0.024 & 0.049 & 0.029 & 14 \\
\hline D4 & 0.021 & 0.020 & 0.025 & & & & 0.022 & 9 \\
\hline $\mathrm{C} 13$ & 1.000 & 1.000 & 1.000 & 0.021 & 0.020 & 0.025 & 0.022 & 15 \\
\hline D5 & 0.031 & 0.033 & 0.044 & & & & 0.036 & 8 \\
\hline C14 & 1.000 & 1.000 & 1.000 & 0.031 & 0.033 & 0.044 & 0.036 & 12 \\
\hline D6 & 0.106 & 0.133 & 0.118 & & & & 0.119 & 4 \\
\hline $\mathrm{C} 15$ & 0.513 & 0.219 & 0.132 & 0.054 & 0.029 & 0.016 & 0.033 & 13 \\
\hline $\mathrm{C} 16$ & 1.457 & 0.781 & 0.376 & 0.154 & 0.104 & 0.044 & 0.101 & 6 \\
\hline D7 & 0.042 & 0.055 & 0.077 & & & & 0.058 & 6 \\
\hline $\mathrm{C} 17$ & 1.000 & 1.000 & 1.000 & 0.042 & 0.055 & 0.077 & 0.058 & 9 \\
\hline D8 & 0.371 & 0.346 & 0.286 & & & & 0.334 & 1 \\
\hline $\mathrm{C} 18$ & 1.000 & 1.000 & 1.000 & 0.371 & 0.346 & 0.286 & 0.334 & 2 \\
\hline D9 & 0.024 & 0.035 & 0.052 & & & & 0.037 & 7 \\
\hline C19 & 1.000 & 1.000 & 1.000 & 0.024 & 0.035 & 0.052 & 0.037 & 11 \\
\hline D10 & 0.010 & 0.014 & 0.023 & & & & 0.015 & 10 \\
\hline $\mathrm{C} 20$ & 1.000 & 1.000 & 1.000 & 0.010 & 0.014 & 0.023 & 0.015 & 16 \\
\hline
\end{tabular}

Thus, it can be seen from Figure 12 that the sub-criteria for safety regulations (C7) and components of explosive operation design (C16) with a score of 0.032 ; sub criteria for environmental conditions (C11) and blast block specifications (C17) with a score of 0.018 ; sub-criteria of geology of area (C10) and environmental anomalies (C20) with a score of 0.005 will be in the next category of sub-criteria.

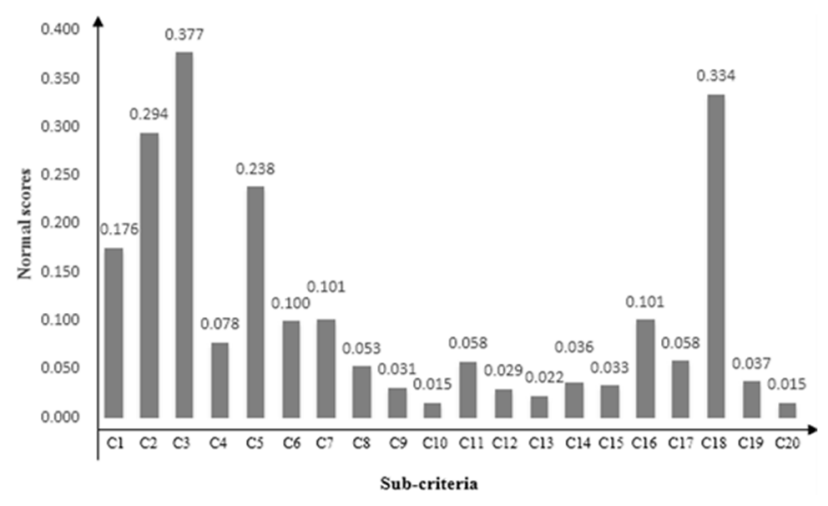

Figure 12. Sub-criteria ranking charts

So, sub-criteria of different categories of criteria can be placed at the same level with equal privileges in the same categories since they simultaneously affect the risk of explosion operations. Effective sub-criteria with equal privileges play the same role in creating the risk of blasting operations. Therefore, the criteria affecting the risk of blasting operations will have an effective impact on both project conditions and the risk of blasting operations. Control of equal priorities is of paramount importance. With the simultaneous occurrence of the risk factors of the blasting operation, project control will be more difficult.

The ranking of risks of blasting operations according to the studies carried out and the opinion of the experts is of particular importance. According to this rating, the most important risks of blasting operations can be identified and attempts can then be made to reduce them. Although blasting operation risks will be ranked according to the importance and impact of the ranking, but considering the conditions of the mining projects it should be noted that all criteria are simultaneously effective and significant. Therefore, control of all priorities is necessary.

Meanwhile, human resources and the effects and results of blasting operations, both of which affect each other, are more important. Manpower is a factor in the occurrence of errors and the creation of adverse conditions in the event of accidents resulting from explosions: it subsequently impacts the operational conditions of the project. Therefore, the evaluation of human resource performance and increase in the level of knowledge and skills and occupational safety and control of all outputs of blasting operations such as fly rock, air blast, and ground vibration is necessary. It should be noted that the severity of the risks is not equal altogether. Some require immediate and urgent action, and others can be scrutinised over a wider range of time. Therefore, selecting the most important project risks and taking actions to remove them is essential for risk management.

\section{CONCLUSIONS}

Due to the complexity of the project, the size of the project, competition and economic and political issues, the need for risk management in projects is inevitable. Because there is no possibility of managing and responding to all identified risks, evaluating and prioritizing risks is critical to managing and responding to them once they have been identified. The existence of risk in projects shows that uncertainty exists in the implementation environment of projects. Fuzzy calculations are a very good tool for modeling and measuring these uncertainties.

The proposed method in this study is the ability to consider the relationship between criteria: it has special features in terms of linguistic variables, qualitative opinions of experts and decision-makers, and their conversion into quantitative variables. With the introduction of fuzzy concepts in order to prioritize the risks of blasting operations, uncertainty - which is the main component of project planning is considered. Because this model has the ability to consider the opinions of several experts or decisionmakers, it is compatible with the nature of project planning, which is premised on group decision-making. As a result, decisions were made according to expert judgment and after considering group decision-making with fuzzy logic to rank the risks of blast operations. Therefore, identifying risk factors, knowing the extent and type of impacts, and their proper ranking is a major step in correct assessment and timely risk responsiveness. 
Determining the risks of blast operations with a set of criteria based on research background studies, field studies, and experts experiences based on a fuzzy AHP approach have been presented. The most important risk factors in blasting operations in accordance with the specified criteria for reducing the risks were identified in ten groups and twenty sub-groups. The comparison of criteria and sub-criteria by using a questionnaire and experts' opinions was done. In evaluating the scores, the criterion Effects and results of blasting operations (D8) was found to have the highest score in terms of effective parameters in producing explosive results and environmental impacts. Subsequently, performance and knowledge of manpower (D1) was the second most effective factor in the risk of blasting operations. On the other hand, the natural hazards (D10) was the last priority of the factors that caused the risk of blasting operations. Also, based on the FAHP method, the lack of control of sub-criteria for health and safety (C3), blast operation results (C18), and knowledge, skill and staffing (C2) as factors affecting the risk of blasting operations are introduced. The two sub-criteria $\mathrm{C} 3$ and $\mathrm{C} 2$ in relation to the $\mathrm{D} 1$ and sub-criterion $\mathrm{C} 18$ in relation to the D8, are considered to be the most effective in the risk of blasting operations. Therefore, it is essential to control these category of criteria and the sub-criteria related to them in blasting operations.

\section{ACKNOWLEDGEMENTS}

The authors would like to thank Mining Engineering Department, Islamic Azad University (South Tehran Branch) for supporting this research.

\section{REFERENCES}

Armaghani, D.J., Hajihassani, M., Mohamad, E.T., Marto, A., \& Noorani, S.A. (2013). Blasting-induced flyrock and ground vibration prediction through an expert artificial neural network based on particle swarm optimization. Arabian Journal of Geosciences, 7(12), 5383-5396.

https://doi.org/10.1007/s12517-013-1174-0

Asri, M., \& Daafi, Y. (2016). Application of cast blasting in Moroccan phosphate mines. Procedia Engineering, (138), 56-63. https://doi.org/10.1016/j.proeng.2016.02.055

Ayhan, M.B. (2013). A fuzzy Ahp approach for supplier selection problem: a case study in a gearmotor company. International Journal of Managing Value and Supply Chains, 4(3), 11-23. https://doi.org/10.5121/ijmvsc.2013.4302

Badri, M.A. (1999). Combining the analytic hierarchy process and goal programming for global facility location-allocation problem. International Journal of Production Economics, 62(3), 237-248.

https://doi.org/10.1016/s0925-5273(98)00249-7

Bajpayee, T.S., Bhatt, S.K., Rehak, T.R., Mowrey, G.L., \& Ingram, D.K. (2003). Fatal accidents due to flyrock and lack of blast area security and working practices in mining. Pennsylvania, United States: National Institute for Occupational Safety and Health Pittsburgh.

Bajpayee, T.S., Rehak, T.R., Mowrey, G.L., \& Ingram, D.K. (2004). Blasting injuries in surface mining with emphasis on flyrock and blast area security. Journal of Safety Research, 35(1), 47-57. https://doi.org/10.1016/j.jsr.2003.07.003

Bajpayee, T.S., Verakis, H.C., \& Lobb, T.E. (2005). Blasting safety - revisiting site security. In $31^{\text {st }}$ Annual Conference on Explosives and Blasting Technique (pp. 1-11). Orlando, Florida, United States: ISEE.
Bakhtavar, E., Nourizadeh, H., \& Sahebi, A.A. (2017). Toward predicting blast-induced flyrock: a hybrid dimensional analysis fuzzy inference system. International Journal of Environmental Science and Technology, 14(4), 717-728. https://doi.org/10.1007/s13762-016-1192-z

Bremer, D., Ethier, R., \& Lilly, D. (2007). Factors driving continuous blasting improvement at the Lafarge Ravena Plant. International Society of Explosives Engineers, 1-6.

Buckley, J.J. (1985). Fuzzy hierarchical analysis. Fuzzy Sets and Systems, 17(3), 233-247. https://doi.org/10.1016/0165-0114(85)90090-9

Calder, C., \& Workman, E. (2008). An analysis of blasting profitability and productivity. Hunter Valley, Australia.

Calder, C., \& Workman, E. (2009). Optimum blasting. Aliteratu review. Hunter Valley, Australia.

Chou, T.-Y., Hsu, C.-L., \& Chen, M.-C. (2008). A fuzzy multicriteria decision model for international tourist hotels location selection. International Journal of Hospitality Management, 27(2), 293-301.

https://doi.org/10.1016/j.ijhm.2007.07.029

Cunningham, C.V.B. (2005). The Kuz-Ram fragmentation model - 20 years. Proceedings 3rd EFEE World Conference on Explosives and Blasting, 201-210.

Dhekne, P.Y. (2015). Environmental impacts of rock blasting and their mitigation. International Journal of Chemical, Environmental \& Biological Sciences, 3(1), 2320-4087.

Ebrahimabadi, A. (2016). Selecting proper plant species for mine reclamation using fuzzy AHP approach (case study: Chadormaloo iron mine of Iran). Archives of Mining Sciences, 61(4), 713-728. https://doi.org/10.1515/amsc-2016-0049

Eloranta, J.W. (2001a). Improve milling through better powder distribution. Proceedings of the Twenty-Seventh Conference of Explosives and Blasting Technique, 28-31.

Eloranta, J.W. (2001b). Optimized iron ore blast designs for SAG/AG Mills. Proceedings of the International Conference on Autogenous and Semiautogenous Grinding Techno$\log y,(1), 262-270$.

Eloranta, J.W. (2007). The effect of fragmentation on mining costs: a literature review. Quebec. Canada: Workshop on the Measurement of Blast Fragmentation-Cost.

Faramarzi, F., Ebrahimi Farsangi, M.A., \& Mansouri, H. (2013). An RES-based model for risk assessment and prediction of backbreak in bench blasting. Rock Mechanics and Rock Engineering, 46(4), 877-887. https://doi.org/10.1007/s00603-012-0298-y

Faramarzi, F., Mansouri, H., \& Ebrahimi Farsangi, M.A. (2013). A rock engineering systems based model to predict rock fragmentation by blasting. International Journal of Rock Mechanics and Mining Sciences, (60), 82-94. https://doi.org/10.1016/j.ijrmms.2012.12.045

Faramarzi, F., Mansouri, H., \& Farsangi, M.A.E. (2014). Development of rock engineering systems-based models for flyrock risk analysis and prediction of flyrock distance in surface blasting. Rock Mechanics and Rock Engineering, 47(4), 1291-1306. https://doi.org/10.1007/s00603-013-0460-1

Ghaeini, N., Mousakhani, M., Amnieh, H.B., \& Jafari, A. (2017). Prediction of blasting-induced fragmentation in Meydook copper mine using empirical, statistical, and mutual information models. Arabian Journal of Geosciences, 10(18), 23-28. https://doi.org/10.1007/s12517-017-3189-4

Ghasemi, E. (2017). Particle swarm optimization approach for forecasting backbreak induced by bench blasting. Neural Computing and Applications, 28(7), 1855-1862. https://doi.org/10.1007/s00521-016-2182-2

Grundstrom, C., Kanchibotla, S.S., Jankovic, A., \& Thornton, D. (2001). Blast fragmentation for maximising the sag mill throughput at Porgera Gold Mine. Proceedings of the Twenty-Seventh Annual Conference on Explosives and Blasting Technique, 1-8. 
Haimes, Y.Y. (2009). Risk modeling, assessment, and management. New Jersey, United States: John Wiley \& Sons. Inc. https://doi.org/10.1002/0471723908

Hamdi, E., \& du Mouza, J. (2005). A methodology for rock mass characterisation and classification to improve blast results. International Journal of Rock Mechanics and Mining Sciences, 42(2), 177-194. https://doi.org/10.1016/j.ijrmms.2004.07.005

Harris, G.W., Mousset, J.P., \& Daemen, J.K. (2001). Measurement of blast induced rock movement in surface mines by application of magnetic geophysics. Transactions of the Institution of Mining and Metallurgy. Section A: Mining Industry, (108), 172-180.

Hasanipanah, M., Jahed Armaghani, D., Monjezi, M., \& Shams, S. (2016). Risk assessment and prediction of rock fragmentation produced by blasting operation: a rock engineering system. Environmental Earth Sciences, 75(9), 808. https://doi.org/10.1007/s12665-016-5503-y

Hoseini, S.M., Sereshki, F., \& Ataei, M. (2016). A quantitative model for evaluation and classification of blastings in openpit mines. Journal of Mining \& Environment, 9(1), 127-141. https://doi.org/10.22044/jme.2016.662

Hsieh, T.Y., Lu, S.-T., \& Tzeng, G.-H. (2004). Fuzzy MCDM approach for planning and design tenders selection in public office buildings. International Journal of Project Management, 22(7), 573-584. https://doi.org/10.1016/j.ijproman.2004.01.002

Kaboli, A., Aryanezhad, M.B., Shahanaghi, K., \& TavakkoliMoghaddam, R. (2007). A holistic approach based on MCDM for solving location problems. International Journal of Engineering Transactions A: Basics, 20(3), 251-262.

Kojovic, T. (2005). Influence of aggregate stemming in blasting on the SAG mill performance. Minerals Engineering, 18(15), 1398-1404.

https://doi.org/10.1016/j.mineng.2005.02.012

Kumar, R., Choudhury, D., \& Bhargava, K. (2016). Determination of blast-induced ground vibration equations for rocks using mechanical and geological properties. Journal of Rock Mechanics and Geotechnical Engineering, 8(3), 341-349. https://doi.org/10.1016/j.jrmge.2015.10.009

Lee, W., Lau, H., Liu, Z., \& Tam, S. (2001). A fuzzy analytic hierarchy process approach in modular product design. Expert Systems, 18(1), 32-42. https://doi.org/10.1111/1468-0394.00153

Marto, A., Hajihassani, M., Jahed Armaghani, D., Tonnizam Mohamad, E., \& Makhtar, A.M. (2014). A novel approach for blast-induced flyrock prediction based on imperialist competitive algorithm and artificial neural network. The Scientific World Journal, (2014), 1-11. https://doi.org/10.1155/2014/643715

Monjezi, M., Bahrami, A., Varjani, A.Y., \& Sayadi, A.R. (2011). Prediction and controlling of flyrock in blasting operation using artificial neural network. Arabian Journal of Geosciences, 4(3-4), 421-425. https://doi.org/10.1007/s12517-009-0091-8

Morin, M.A., \& Ficarazzo, F. (2006). Monte Carlo simulation as a tool to predict blasting fragmentation based on the KuzRam model. Computers \& Geosciences, 32(3), 352-359. https://doi.org/10.1016/j.cageo.2005.06.022

Mosher, J.B. (2005). Comminution circuits for gold ore processing. Advances in Gold Ore Processing, 253-277. https://doi.org/10.1016/s0167-4528(05)15012-1

Petkovic, J., Sevara, Z., Jaksic, M.L., \& Marinkovic, S. (2012). Application of fuzzy AHP method for choosing a technology within service company. Technics Technologies Education Management, 7(1), 332-341.

Raina, A.K., Murthy, V.M.S.R., \& Soni, A.K. (2015). Flyrock in surface mine blasting: understanding the basics to develop a predictive regime. Current Science, 108(4), 660-665.
Rezaei, M., Monjezi, M., \& Yazdian Varjani, A. (2011). Development of a fuzzy model to predict flyrock in surface mining. Safety Science, 49(2), 298-305. https://doi.org/10.1016/j.ssci.2010.09.004

Rikalovic, A., Cosic, I., Labati, R.D., \& Piuri, V. (2017). A comprehensive method for industrial site selection: the macrolocation analysis. IEEE Systems Journal, 11(4), 2971-2980. https://doi.org/10.1109/jsyst.2015.2444471

Ryu, D.W., Shim, H.J., Han, C.Y., \& Ahn, S.M. (2006). Prediction of rock fragmentation and design of blasting pattern based on 3-D spatial distribution of rock factor. International Journal of Rock Mechanics and Mining Sciences, 46(2), 326-332.

Saadat, M., Khandelwal, M., \& Monjezi, M. (2014). An ANNbased approach to predict blast-induced ground vibration of Gol-E-Gohar iron ore mine, Iran. Journal of Rock Mechanics and Geotechnical Engineering, 6(1), 67-76. https://doi.org/10.1016/j.jrmge.2013.11.001

Saaty, T.L. (1980). The analytical hierarchy process. New York, United States: Mc-Graw-Hill.

Safari, M., Ataei, M., Khalokakaie, R., \& Karamozian, M. (2010). Mineral processing plant location using the analytic hierarchy process - a case study: the Sangan iron ore mine (phase 1). Mining Science and Technology (China), 20(5), 691-695. https://doi.org/10.1016/s1674-5264(09)60264-7

Sayadi, A., Monjezi, M., \& Sharifi, M. (2013). A risk assessment in open pit mines using Fuzzy TOPSIS and FAHP. Journal of Analytical and Numerical Methods in Mine Engineering, (6), 45-58.

Sayadi, A., Monjezi, M., Talebi, N., \& Khandelwal, M. (2013). A comparative study on the application of various artificial neural networks to simultaneous prediction of rock fragmentation and backbreak. Journal of Rock Mechanics and Geotechnical Engineering, 5(4), 318-324. https://doi.org/10.1016/i.jrmge.2013.05.007

Seccatore, J., Origliasso, C., \& De Tomi, G. (2013). Assessing a risk analysis methodology for rock blasting operations. Blasting in Mining - New Trends, 51-60. https://doi.org/10.1201/b13739-7

Singh, P.K., Roy, M.P., Paswan, R.K., Sarim, M.D., Kumar, S., \& Ranjan Jha, R. (2016). Rock fragmentation control in opencast blasting. Journal of Rock Mechanics and Geotechnical Engineering, (8), 225-237.

Singh, S.P., \& Yalcin, T. (2002). Effects of muck size distribution on scooping operations. Proceedings of $28^{\text {th }}$ Annual Conference on Explosives and Blasting Techniques, (1), 315-326.

Singh, S.P., Yalcin, T., Glogger, M., \& Narendrula, R. (2003). Interaction between the size distribution of the muck and the loading equipment. Proceedings of the $4^{\text {th }}$ International Conference on Computer Applications in Mineral Industries, 1-13.

Taji, M. (2008). The classification of open pit mine blast results by BBSR. Proceedings of the 1 the National Symposium on Blasting Engineering and Industrial Explosives, 1-6.

Taji, M., \& Bagheri, B. (2015). A quantitative method to environmental effects of blasting operation in open pit mines. In $2^{\text {ed }}$ National Conference on Planning-Conservation of Environmental Protection and Sustainable Development (pp. 1-10). Tehran, Iran: Shahid Beheshti University International Conference Center.

Taji, M., Ataei, M., Goshtasbi, K., \& Osanloo, M. (2012). ODM: a new approach for open pit mine blasting evaluation. Journal of Vibration and Control, 19(11), 1738-1752. https://doi.org/10.1177/1077546312439911

Tripathy, G.R., Shirke, R.R., \& Kudale, M.D. (2016). Safety of engineered structures against blast vibrations: a case study. Journal of Rock Mechanics and Geotechnical Engineering, $8(2), 248-255$. https://doi.org/10.1016/j.jrmge.2015.10.007

Trivedi, R., Singh, T.N., \& Raina, A.K. (2014). Prediction of blast-induced flyrock in Indian limestone mines using neural 
networks. Journal of Rock Mechanics and Geotechnical Engineering, 6(5), 447-454. https://doi.org/10.1016/i.jrmge.2014.07.003

Verakis, H. (2011). Flyrock: a continuing blast safety threat. Journal of Explosives Engineering, 28(4), 32-36.

Workman, L. (2001). An analysis of blasting profitability and productivity. Hunter Valley, Australia.

Workman, L., \& Eloranta, J. (2008). The effects of blasting on crushing and grinding efficiency and energy consumption, $1-10$

Yari, M., Bagherpour, R., \& Jamali, S. (2017). Development of an evaluation system for blasting patterns to provide efficient production. Journal of Intelligent Manufacturing, 28(4), 975-984. https://doi.org/10.1007/s10845-015-1036-6
Yuvka, S., Beyhan, S., \& Uysal, O. (2017). The effect of the number of holes on blast-induced ground vibrations. Environmental Earth Sciences, 76(17), 620-624. https://doi.org/10.1007/s12665-017-6959-0

Zadeh, L.A. (1965). Fuzzy sets. Information and Control, $8(3), 338-353$. https://doi.org/10.1016/s0019-9958(65)90241-x

Zadeh, L.A. (1975a). The concept of a linguistic variable and its application to approximate reasoning-I. Information Sciences, 8(3), 199-249. https://doi.org/10.1016/0020-0255(75)90036-5

Zadeh, L.A. (1975b). The concept of a linguistic variable and its application to approximate reasoning-II. Information Sciences, 8(4), 301-357. https://doi.org/10.1016/0020-0255(75)90046-8

\section{ОЦІНКА РИЗИКУ ПРОВЕДЕННЯ ВИБУХОВИХ РОБІТ У ВІДКРИТИХ КАР'СРАХ ІЗ ВИКОРИСТАННЯМ НЕЧІТКОГО МЕТОДУ АНАЛІЗУ ІЕРАРХІЙ (НМАІ)}

\section{М. Кіані, С.Х. Хоссейні, М. Таджі, М. Голінеджад}

Мета. Визначення ризиків проведення вибухових робіт та їх оцінка на основі використанням нечіткого методу аналізу ієрархій (HMAI) для покращення управління якістю проектів.

Методика. В рамках даного дослідження, проблеми визначення та оцінки ризиків вибухових робіт розглядалися із застосуванням нечіткого методу аналізу ієрархій. На базі аналізу історичних даних і польового дослідження з урахуванням експертних оцінок були визначені критерії та підкритерії для побудови ісрархій.

Результати. За результатами HMAI, неконтролюючий підкритерій здоров'я та безпеки (C3), підкритерій результатів вибухових робіт (C18), знань, умінь і кадрів (С2) зі значеннями $0.377,0.334$ і 0.294 відповідно найбільш ефективні в появі ризику проведення вибухових робіт. Підкритерій $\mathrm{C} 18$ чинить найбільший вплив на ризик проведення вибухових робіт. Критерій результатів і наслідків вибухових робіт (D8) з найефективнішим значенням 0.334 та критерій природних катастроф (D10) зі значенням 0.015 є останніми пріоритетами серед чинників, які визначають ризик проведення вибухових робіт.

Наукова новизна. Отримав доповнення та подальший розвиток науково-методичний підхід до визначення ризиків при проведенні вибухових робіт, заснований на їх ранжуванні з використанням системи виявлених критеріїв і підкритеріїв методом НMAI.

Практична значимість. Для успішного керування проектом важливо визначати найсерйозніші ризики проекту й вжити заходів щодо їх усунення. Відносно ранжирування ризиків проведення вибухових робіт управління підкритеріями C3, C18 і C2, а також критерієм D8, особливо важливо для зниження цих ризиків та покращення якості управління проектом.

Ключові слова: вибухові роботи, відкритий кар'єр, оцінка ризику, метод НMAI, критерії та підкрітерії

\section{ОЦЕНКА РИСКА ПРОВЕДЕНИЯ ВЗРЫВНЫХ РАБОТ В ОТКРЫТЫХ КАРЬЕРАХ С ИСПОЛЬЗОВАНИЕМ НЕЧЕТКОГО МЕТОДА АНАЛИЗА ИЕРАРХИЙ (НМАИ)}

\section{М. Киани, С.Х. Хоссейни, М. Таджи, М. Голинеджад}

Цель. Определение рисков проведения взрывных работ и их оценка на основе использования нечеткого метода анализа иерархий (НМАИ) для улучшения управления качеством проектов.

Методика. В рамках данного исследования, проблемы определения и оценки рисков взрывных работ рассматривались с применением нечеткого метода анализа иерархий. На базе анализа исторических данных и полевого исследования с учетом экспертных оценок были определены, критерии и подкритерии для построения иерархий.

Результаты. По результатам НМАИ, неконтролирующий подкритерий здоровья и безопасности (С3), подкритерий результатов взрывных работ (C18), знаний, умений и кадров $(\mathrm{C} 2)$ со значениями $0.377,0.334$ и 0.294 соответственно наиболее эффективны в появлении риска проведения взрывных работ. Подкритерий С18 оказывает самое большое влияние на риск проведения взрывных работ. Критерий результатов и последствий взрывных работ (D8) с самым эффективным значением 0.334 и критерий природных катастроф (D10) со значением 0.015 являются последними приоритетами среди факторов, которые определяют риск проведения взрывных работ.

Научная новизна. Получил дополнение и дальнейшее развитие научно-методический подход к определению рисков при проведении взрывных работ, основанный на их ранжировании с использованием системы выявленных критериев и подкритериев методом НМАИ.

Практическая значимость. Для успешного руководства проектом важно определять самые серьезные риски проекта и предпринять действия по их устранению. В отношении ранжирования рисков проведения взрывных работ управление подкритериями $\mathrm{C} 3, \mathrm{C} 18$ и $\mathrm{C} 2$, а также критерием $\mathrm{D} 8$, особенно важно для снижения этих рисков и улучшения руководства проектом.

Ключевые слова: взрывные работы, открытый карьер, оценка риска, метод НМАИ, критерии и подкритерии 


\section{ARTICLE INFO}

Received: 2 June 2019

Accepted: 16 August 2019

Available online: 3 Septrmber 2019

\section{ABOUT AUTHORS}

Mohamad Kiani, Master of Sciences, PhD Student of the Mining Engineering Department, Islamic Azad University (South Tehran Branch), Pirouzi St, Abouzar Blvd (Ahgang Hwy), 1777613651, Tehran, Iran. E-mail: mo.kiani@yahoo.com Seyed Hamid Hosseini, Doctor of Philosophy, Assistant Professor of the Mining Engineering Department, Islamic Azad University (South Tehran Branch), Pirouzi St, Abouzar Blvd (Ahgang Hwy), 1777613651, Tehran, Iran. E-mail: hoseini@azad.ac.ir

Mohamad Taji, Doctor of Philosophy, Assistant Professor of the Petroleum and Mining Engineering Department, Islamic Azad University (Shroud Branch), University Blvd, 3619943189, Shahrood, Iran. E-mail: Taji@ymail.com

Mehran Gholinejad, Doctor of Philosophy, Assistant Professor of the Mining Engineering Department, Islamic Azad University (South Tehran Branch), Pirouzi St, Abouzar Blvd (Ahgang Hwy), 1777613651, Tehran, Iran. E-mail: $\underline{\text { m_qolinejad@azad.ac.ir }}$ 